ORIGINAL ARTICLE

\title{
静脈血栓塞栓症合併肺癌症例の血栓治療に関する検討
}

\author{
池澤靖元 1 ・榊原 純 1 庄司哲明 1 高島雄太 1 森本 恵 1 ・ \\ 菊池 創 $1 \cdot$ 高階太一 $1 \cdot$ 大泉聡史 $1 \cdot$ 辻野一三 $1 \cdot$ 西村正治 1
}

\section{An Analysis of Anticoagulation Treatment for Cancer Patients with Newly Diagnosed VTE}

Yasuyuki Ikezawa1; Jun Sakakibara1; Tetsuaki Shoji1; Yuta Takashima1; Megumi Morimoto1; Hajime Kikuchi1; Taichi Takashina1; Satoshi Oizumi1; Ichizo Tsujino1; Masaharu Nishimura1

${ }^{1}$ First Department of Medicine, Hokkaido University School of Medicine, Japan.

ABSTRACT - Objective. Patients with lung cancer have a higher risk for venous thromboembolism (VTE). Anticoagulation treatment for VTE is important in addition to the treatment for lung cancer. Warfarin is one of the anticoagulation treatments for VTE, however, recurrence of VTE is often problematic during warfarin treatment. In January 2012, the subcutaneous injection of heparin calcium at home was covered by health insurance in Japan, which may be added to potential anticoagulation treatment for VTE. Methods. We conducted a retrospective analysis of 29 patients who received initial anticoagulation treatment, including a heparin injection into the vein, and were subsequently treated with warfarin among 39 lung cancer patients with newly diagnosed VTE in the First Department of Medicine, Hokkaido University Hospital, between October 2006 and April 2014. Results. Eleven patients had recurrence of VTE. Of these, 9 patients received a subcutaneous injection of heparin calcium and 1 patient received fondaparinux sodium and responded. Although all 9 patients ultimately died of cancer, the subcutaneous injection of heparin calcium enabled 2 patients to continue to receive chemotherapy and ambulatory treatments for VTE without recurrence of VTE. Conclusions. This study demonstrates that patients with recurrence of VTE can continue to receive regular ambulatory chemotherapy for cancers in combination with the subcutaneous injection of heparin calcium at home.

(JJLC. 2015;55:1001-1007)

KEY WORDS — Venous thromboembolism, Anticoagulation, Lung cancer, Warfarin, Heparin calcium

Reprints: Jun Sakakibara, First Department of Medicine, Hokkaido University School of Medicine, North 15, West 7, Kita-ku, Sapporo, Hokkaido 060-8648, Japan (e-mail: konishj@med.hokudai.ac.jp).

Received June 4, 2015; accepted August 25, 2015.

要旨一一目的. 肺癌において静脈血栓塞栓症 (VTE) の 合併はしばしば認められ, 抗凝固療法は肺癌治療ととも に重要である。ワルファリン内服はVTEに対する抗凝 固療法の選択肢の一つだが, 内服中の VTEの再発・増 悪が問題となる場合も多い. 本邦でも 2012 年 1 月よりへ パリンカルシウム在宅自己注射が保険適応となり，抗凝 固治療の選択肢が広がってきている．方法．2006 年 10 月から 2014 年 4 月に, 北海道大学病院内科 I で肺癌に VTE を合併した 39 例中, ヘパリンなどの初期治療導入 後, ワルファリン単独内服治療に移行できた 29 例を後ろ
向きに検討した. 結果. 29 例中, VTEの再発を 11 例認 めた. そのうち 10 例はへパリンカルシウムまたは Xa 阻害薬であるフォンダパリヌクスナトリウムの皮下注射 に変更され, 全例でVTE はコントロールされた. 11 例中 9 例は原病の悪化で死亡したが, 残り 2 例はへパリンカ ルシウム在宅自己注射導入後, VTE の増悪を認めず外来 治療継続中である。結論. 肺癌に合併したワルファリン 不応性 VTE 症例において, ヘパリンカルシウム在宅自 己注射導入は有用な治療戦略である可能性が示唆され た。 


\section{はじめに}

担癌状態における静脈血栓塞栓症（venous thromboembolism ; 以下 VTE) の合併はTrousseau が 1865 年に報告して以来1多数報告を認めるが，その機序に関 しては今なお未解明な部分も多い. $2-4$ またVTEを合併 した癌患者, 特に肺癌においては非合併症例と比較して 予後不良であることが報告されている. 5 癌患者におけ るVTE に対する初期治療は, American Society of Clinical Oncology や European Society for Medical Oncology などの国際的なガイドラインにおいて通常は未分画/低 分子へパリン, Xa 阻害薬の投与が推奨されている. 6,7 長 期投与においては, ヘパリンが継続使用できない場合に ワルファリン内服は許容されているが, ワルファリン治 療中の VTE 再発率は 17 21（\%)と，ヘパリンでの再発 が6〜10（\%）に対して高いことが報告されている.8 8 本ではヘパリンカルシウム在宅自己皮下注射が保険適応 でなかったため, 以前は長期的な VTEの制御のために ヘパリン投与からワルファリンの内服への切り替えが一 般的に施行されていた. 10 しかし，2012 年 1 月よりへパ リンカルシウムの在宅自己皮下注射が血栓塞栓症（動脈 血栓症, 心筋梗塞症, 肺塞栓症, 脳塞栓症, 四肢動脈血 栓塞栓症, 手術中・術後の血栓塞栓症など）の治療及び 予防に対して保険適応となり, 抗凝固治療の選択肢が広 がってきた，そのような背景を踏まえ今回我々は，当科 におけるVTEを合併した肺癌患者のうち, ワルファリ ン内服による維持抗凝固療法を行った症例の臨床学的特 徵や治療経過, ワルファリンに対する反応性などを後ろ 向きに検討した.

\section{対象と方法}

2006 年 10 月から 2014 年 4 月に北海道大学病院内科 I において, 肺癌にVTE (深部静脈血栓症, 肺動脈塞栓症 を含む)を合併した 39 例のうち，ワルファリンを含む抗 凝固療法を施行した 29 例を対象とした.ワルファリン単 独内服切り替え後の VTEの再発の有無, 臨床学的因子 や治療経過を後ろ向きに検討した. 初回 VTEの診断は 造影 CT もしくは静脈エコーを用いてすべての症例で血 栓を確認した. 今回我々はVTEの再発の定義に関して, ワルファリン単独内服切り替え後の維持抗凝固療法中 に, (1)造影 CT やエコーなどの画像上の新規血栓の出現, (2)下腿浮腫・疼痛などの血栓症状の出現, (3) D-dimer の明らかな増悪を認めるが, 臨床的に他にD-dimerの上
昇する原因を認めない, 11 のいずれかを満たした場合と 定義した. D-dimer の推移の統計学的検討には分散分析 法を用いて分析した。生存期間は初回のVTE発症日か ら死亡日までと定義して, 生存率に関してはカプランマ イヤー法を用いて分析した．有意差検定はLog-rank 検 定にて行った.

\section{結 果}

\section{1. 患者背景}

患者背景を Table 1 に示す. 当院で対象期間内に肺癌 にVTEを合併しワルファリン単独内服に切り替えた 29 例のうち, VTEの再発を認めた症例は 11 例（以下再発 群）であった．組織型に関して再発群では全例腺癌であ り，そのうち 4 例が粘液産生腫瘍であった。ワルファリ ン単独内服に切り替えたあとに再発を起こさなかった群 (以下無再発群) (18 例) では腺癌/扁平上皮癌/大細胞神 経内分泌癌/非小細胞癌/小細胞癌 $11 / 1 / 1 / 2 / 3$ で, 有意に 再発群では腺癌が多かった $(\mathrm{p}=0.01)$. 無再発群のうち腺 癌 2 例が粘液産生腫瘍であった. その他の患者背景因子 に関しては両群に特に有意差を認めなかった. 初回 VTE 診断時における自覚症状を Table 2 に示す. 下腿浮腫 3 例, 下腿疼痛 2 例, 胸痛 1 例, 脳梗塞 1 例であった。一 方, 無症状ではあるが CT 検査で偶然発見もしくは Ddimerの変化を認め, 画像的に血栓を指摘された症例が 22 例であった.

\section{2. 治療経過}

再発群・無再発群のVTE 初回発症時の初期治療を Table 3 に示す. 初期治療は全例へパリンの持続静注も しくはフォンダパリヌクスナトリウムの皮下注射が施行 され，その後ワルファリン内服を併用し最終的には全例 でワルファリン単独内服となった．ワルファリンの効果 はPT 及び PT-INR のモニターにより治療域を確認し内 服を継続していた. VTE に対する初期治療からワルファ リン単独への切り替えまでの期間中央值は 5.5 日間で あった．全症例におけるワルファリン単独内服期間中央 值は 142 日間で, 無再発群においては 267 日間, 再発群 では 21 日間であった. 初回 VTE 発症から再発までの期 間中央值は 31 日間であった. VTE 再発の診断は, (1)新規 血栓の出現 3 例, (2)血栓症状の出現 6 例, (3) D-dimer の再上昇のため治療薬変更が 7 例であった. VTE 再発時 全例全身化学療法中であり, その治療内容を Table 4 に 示す. 治療効果は 9 例がPD (progressive disease), 2 例はSD (stable disease) であった。再発後 1 例は全身状 
Table 1. Clinical Characteristics of Patients with VTE

\begin{tabular}{|c|c|c|c|c|}
\hline & & $\begin{array}{l}\text { No recurrence } \\
\text { group }\end{array}$ & $\begin{array}{l}\text { Recurrence } \\
\text { group }\end{array}$ & $\mathrm{p}$ value \\
\hline $\mathrm{n}$ & & 18 & 11 & \\
\hline \multirow[t]{2}{*}{ Gender } & Male & 10 & 4 & 0.28 \\
\hline & Female & 8 & 7 & \\
\hline Age (yr) & Median (range) & $64(45-79)$ & $62(45-79)$ & 0.89 \\
\hline \multirow[t]{2}{*}{ Smoking history } & Yes & 13 & 6 & 0.38 \\
\hline & No & 5 & 5 & \\
\hline \multirow[t]{5}{*}{ Histological type } & Adenocarcinoma & 11 & 11 & 0.01 \\
\hline & Squamous cell carcinoma & 1 & 0 & \\
\hline & Large cell neuroendocrine carcinoma & 1 & 0 & \\
\hline & Non-small cell carcinoma & 2 & 0 & \\
\hline & Small cell carcinoma & 3 & 0 & \\
\hline \multirow[t]{6}{*}{ Clinical stage } & I & 3 & 0 & 0.23 \\
\hline & II & 1 & 0 & \\
\hline & IIIA & 1 & 0 & \\
\hline & IIIB & 4 & 1 & \\
\hline & IV & 5 & 10 & \\
\hline & Recurrence after surgery & 4 & 0 & \\
\hline \multirow[t]{4}{*}{ Performance status } & 0 & 6 & 2 & 0.4 \\
\hline & 1 & 9 & 6 & \\
\hline & 2 & 0 & 3 & \\
\hline & 3 & 3 & 0 & \\
\hline \multirow[t]{2}{*}{ Chemotherapy } & Yes & 16 & 10 & 0.95 \\
\hline & No & 2 & 1 & \\
\hline \multirow[t]{2}{*}{ Radiation } & Yes & 15 & 8 & 0.48 \\
\hline & No & 3 & 3 & \\
\hline \multirow[t]{2}{*}{ IVC filter } & Yes & 7 & 2 & 0.4 \\
\hline & No & 11 & 9 & \\
\hline \multirow[t]{3}{*}{ The region of the thrombus } & Vein of the lower legs & 9 & 7 & 0.41 \\
\hline & Pulmonary artery & 3 & 2 & \\
\hline & Both & 6 & 2 & \\
\hline
\end{tabular}

Table 2. Symptoms of Newly Diagnosed VTE

\begin{tabular}{lr}
\hline Swelling of the lower legs & 3 \\
Pain in the lower legs & 2 \\
Chest pain & 1 \\
Stroke & 1 \\
None & 22 \\
\hline
\end{tabular}

態の増悪のため抗凝固療法は中止したが, 残り 10 例にお いてへパリンもしくはフォンダパリヌクスによる治療に 変更し, VTEの制御が得られた.うち 2 例はへパリンカ ルシウム在宅自己皮下注射の導入でVTEの増悪を認め ず外来移行し，治療継続中である.

\section{3. 再発時における D-dimer の推移}

初回 VTE 診断からの D-dimer の経過を Figure 1 に 示す.VTE 発症時はいずれの症例においても当院の cut off 值 $1.0 \mu \mathrm{g} / \mathrm{dl}$ を超えていた．再発群における D-dimer
に関して, 初回 VTE 発症時点(平均士標準偏差 $\mu \mathrm{g} / \mathrm{ml}$ ：

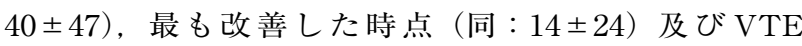
が再発した時点（同：38土41）での実測值をグラフ化し た. 最も改善した時点と比較し, 再発時は D-dimer の上 昇傾向を認めた (Figure 1a)，無再発群においては治療前 と比較すると有意に D-dimer は改善しており，3 ケ月経 過をしても D-dimerの上昇は認められなかった（Figure 1b).

\section{4. 生存期間}

再発群と無再発群の肺癌診断時からの生存曲線を Figure 2 に示す. 無再発群・再発群ともに死因は全例が肺癌 悪化による原病死であった. 平均生存期間は全症例 (Figure 2a）で再発群 34（土52）週, 無再発群は $139 （ \pm 309 ）$ 週及び進行期症例（Stage IIIB/IV/術後再発) (Figure

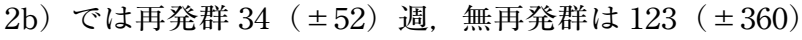
週で，いずれにおいても予後不良であった $(\mathrm{p}=0.009, \mathrm{p}=$ 0.025).さらにVTE 初発診断時からの生存曲線を Figure 3 に示す. 平均生存期間は全症例 (Figure 3a) におい 
Table 3. First-treatment Regimens for VTE in the Recurrence Group and No Recurrence Group

\begin{tabular}{lcc}
\hline & $\begin{array}{c}\text { No recurrence } \\
\text { group }\end{array}$ & $\begin{array}{c}\text { Recurrence } \\
\text { group }\end{array}$ \\
\hline Unfractionated heparin & 9 & 6 \\
Low molecular weight heparin & 1 & 1 \\
Fondaparinux sodium & 7 & 2 \\
Warfarin & 1 & 2 \\
\hline The combination of warfarin at the beginning & 8 & 1 \\
\hline
\end{tabular}

Table 4. Chemotherapy Regimens Administered During VTE Recurrence

\begin{tabular}{ll}
\hline CBDCA + PTX & 2 \\
CBDCA + GEM & 1 \\
CBDCA + PEM & 1 \\
PEM & 2 \\
VNR & 1 \\
Gefitinib & 4 \\
\hline
\end{tabular}

CBDCA: carboplatin, PTX: paclitaxel, GEM: gemcitabine, PEM: pemetrexed, VNR: vinorelbine.

て再発群 $22( \pm 12)$ 週, 無再発群は $65( \pm 85)$ 週より有 意に再発群の方が予後不良であり $(\mathrm{p}=0.016)$, 進行期症 例（Figure 3b）に打いても再発群 22（土12）週，無再発 群 $60 （ \pm 78 ）$ 週で予後不良な傾向にあった（p=0.062）.

\section{考 察}

担癌患者に扔けるVTEの発生危険率は非担癌患者と 比較すると 10 倍程度の上昇を認めると報告されてい る. ${ }^{12}$ 臟器別の検討では原発性肺癌は $10 \%$ 程度の合併 率であり, 13 特に腺癌に多い. 14,15 癌細胞における凝固 充進の機序として，1）腫瘍及び腫瘍壊死が㠜固促進物質 を産生・放出（組織因子，第 X 因子を直接活性化する癌 プロコアグラントなど）し，第 VII 因子や X 因子を活性 化する，2）腫瘍細胞がサイトカイン（IL-1，TNF など） を誘導し血管内皮における組織因子の産生を㐫進する,

3）腫瘍細胞による血小板凝集の立進，などがあげられ る. 16 さらに腺癌にVTE 合併が多い理由に関しては, 1) ムチン産生腺癌でのプロコアグラント分泌，2) ムチンに よる血小板活性化，3)腫瘍により活性化された単球やマ クロファージから放出された炎症性サイトカインによる 血管内皮傷害や組織因子の活性化，などの報告があ る. $2,17,18$ 今回の当科の検討でも腺癌 22 例中 6 例 (再発群 11 例中 4 例，無再発群 18 例中 2 例）で粘液産生腫瘍で あった. また当科の Sato らは血中組織因子が著明に高值 を示したVTE 合併肺癌を報告しており，肺癌産生の組
織因子が血栓形成に関与していることを示した. 19 この ような凝固充進に対して，ヘパリンはアンチトロンビン と結合し，アンチトロンビンがトロンビンや活性化 X 因子 $(\mathrm{Xa})$ を阻害することにより抗凝固作用を発揮する. そのほかに外因性経路阻害因子の放出により，様々な血 漿・血小板蛋白, 内皮細胞, 白血球と結合し, 血小板抑 制，血管透過性立進に作用し，広く抗凝固作用を有する ことで担癌患者に打ける血栓抑制に機能すると考えられ る. 20 一方で癌患者におけるワルファリン治療中の再発 の機序・原因として, ワルファリンはビタミン $\mathrm{K}$ 拮抗作 用によりビタミン $\mathrm{K}$ 依存凝固因子（第 II, VII, IX, X 因子）の合成阻害を行うが，それらの因子以外の癌に伴 う凝固充進作用の抑制に乏しい可能性が一つの要因とし て考えられる.ささらに，1）薬物相互作用，2）全身状態 の悪化に伴うワルファリン経口摂取困難, 3) 癌進行や化 学療法など治療薬による肝障害などの理由で, PT-INR を治療域に保つ難しさの影響が考えられた。今回の検討 ではワルファリンの治療域であったにもかかわらず血栓 の増悪が起きて抢り，上記機序に加えてワルファリン治 療再発群で腺癌が有意に多かったことより, 腺癌が血栓 症の初発だけでなくワルファリン治療中のVTEの再発 リスクの上昇にも関与する可能性が示唆された。

Palareti らはVTEを発症した患者に対して抗凝固療 法治療後の VTE 再発の有無の指標として D-dimer の検 討を行った．抗凝固療法終了後正常化していた D-dimer が再上昇し、VTEが再発した症例は $6.2 \%$ あり, VTE 再発の指標として D-dimerの推移の有用性を示してい る. 21 今回の検討でも, D-dimer はVTE の治療効果及び その治療中の再発の有無の指標として有用である可能性 が示された．特にVTEによる自覚症状を認めない場合 も D-dimer が上昇傾向の場合には画像的検索などを施 行し，VTEの有無を確認する必要性が示唆された。

固形癌に扔いてVTE コントロールが予後と関連があ り,22-24 VTE を発症した肺癌患者では発症から死亡まで の平均生存期間が 22 36 週間, さらに早期に肺動脈血栓 症を合併した症例では平均生存期間が 12 週と, 予後不良 であることが報告されている. 25 今回の検討において肺 


\section{a) Recurrence group}

$(\mu \mathrm{g} / \mathrm{ml})$

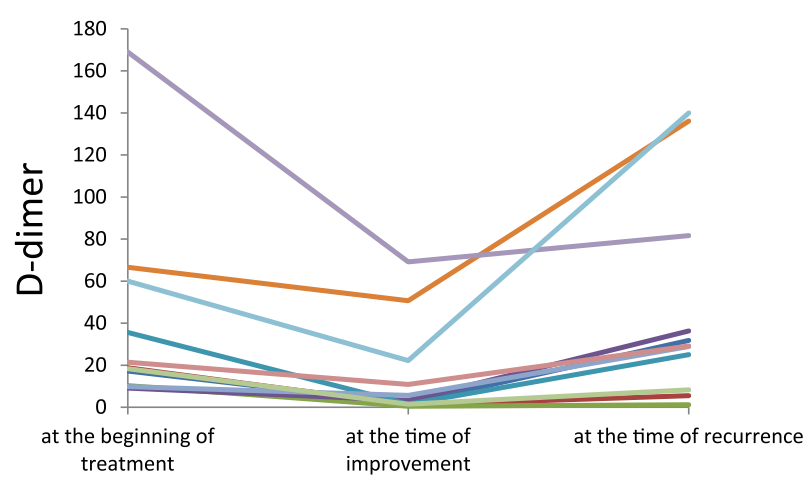

\section{b) No recurrence group} $(\mu \mathrm{g} / \mathrm{ml})$

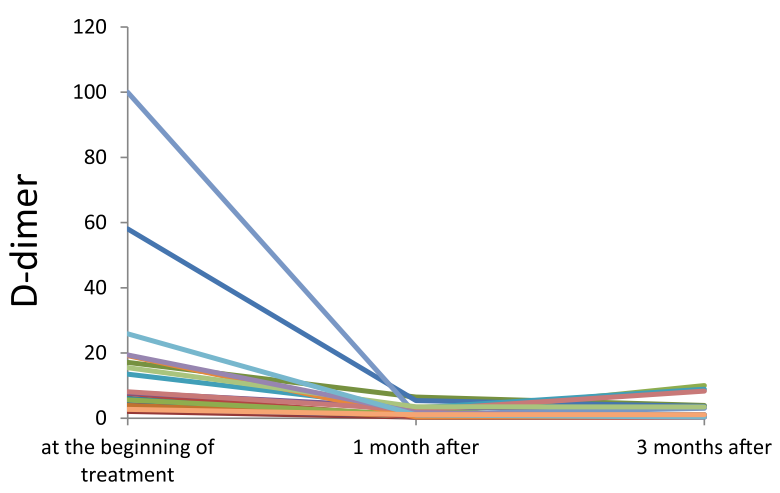

Figure 1. The change in the D-dimer score following anticoagulation treatment for patients with VTE. a) In recurrence group, the D-dimer increases at recurrence of VTE. b) Conversely, in the no recurrence group, the D-dimer has no change following anticoagulation treatment.

\section{a) All stages}

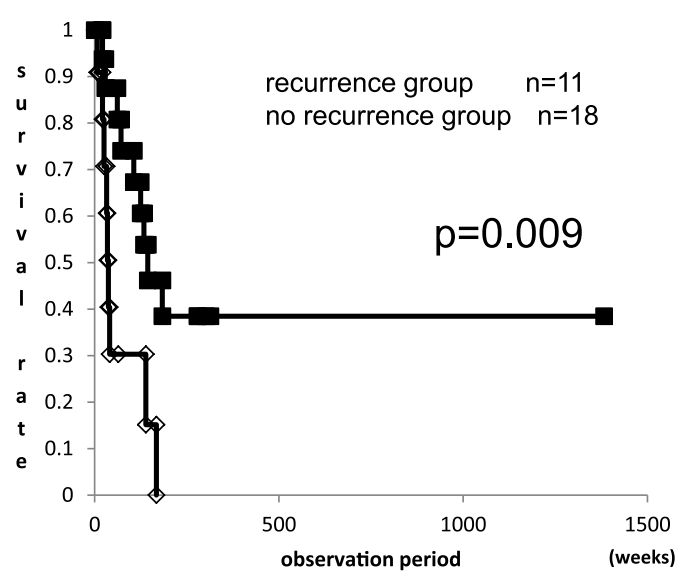

\section{b) Advanced stages}

(Stage IIIB/IV/recurrence)

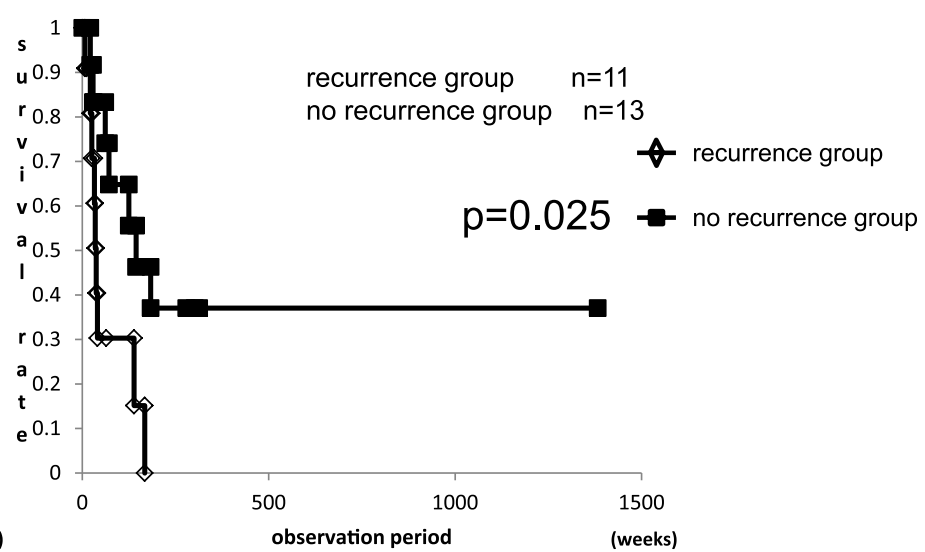

Figure 2. Survival curves for a) all patients and b) patients with advanced disease in the recurrence and no recurrence groups after lung cancer was diagnosed. The survival time of $\mathbf{a})$ all patients and $\mathbf{b}$ ) patients with advanced disease in the recurrence group was significantly shorter than those in the no recurrence group (a) $p=0.009, \mathbf{b}) \mathrm{p}=$ $0.025)$.

癌診断時及びVTE 発症後の平均生存期間に関して, 再 発群は無再発群と比較して統計学的有意差をもって予後 不良であった。それゆえ今回の検討からも，以前の報告 と同様にVTEのコントロールが予後不良因子になりう ると考えられた。

本邦は諸外国と違い 2011 年まではへパリンカルシウ ムの在宅自己皮下注射が保険適応でなかったため, VTE 治療としてワルファリン内服による維持治療が行われて いた。ワルファリン内服中の VTE 再発時の治療法は明 確には定められていない。しかし今回再発を認めた全症 例に打いてヘパリンもしくはフォンダパリヌクスへの切
り替えによりVTEのコントロールが得られ，うち2 例 はヘパリンカルシウムの在宅自己皮下注射を行いながら 全身化学療法を継続できた。ワルファリン治療再発後の ヘパリンカルシウムの在宅自己皮下注射は外来治療移行 への重要な選択肢と考えられた.ささらに効果や認容性で, ワルファリンとの非劣性が示された edoxaban などの新 規薬剤の開発で選択肢が広がってきて抢り, 26 本邦でも VTE の治療のために 2014 年に edoxaban が使用可能と なったそそのため症例ごとに併用薬剤の相互作用, 癌治 療の入院治療から在宅治療への移行なども踏まえ, 最適 なVTEの治療方法に関して今後もさらなる検討を重ね 
a) All stages

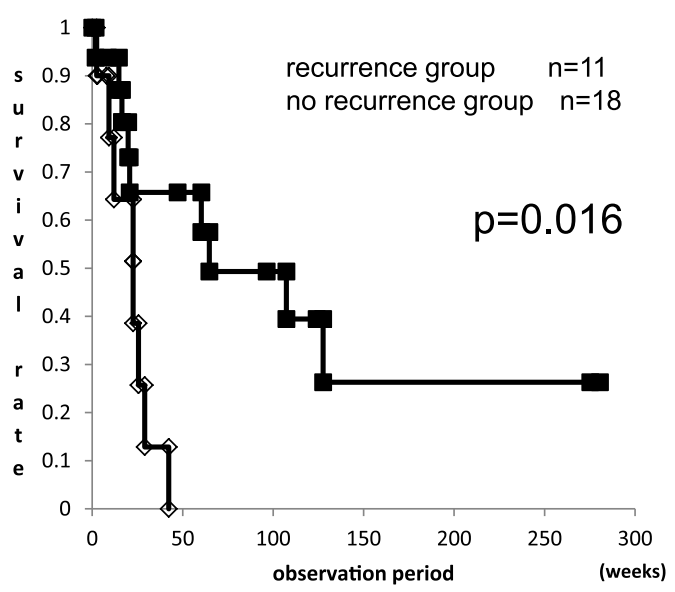

b) Advanced stages

(Stage IIIB/IV/recurrence)

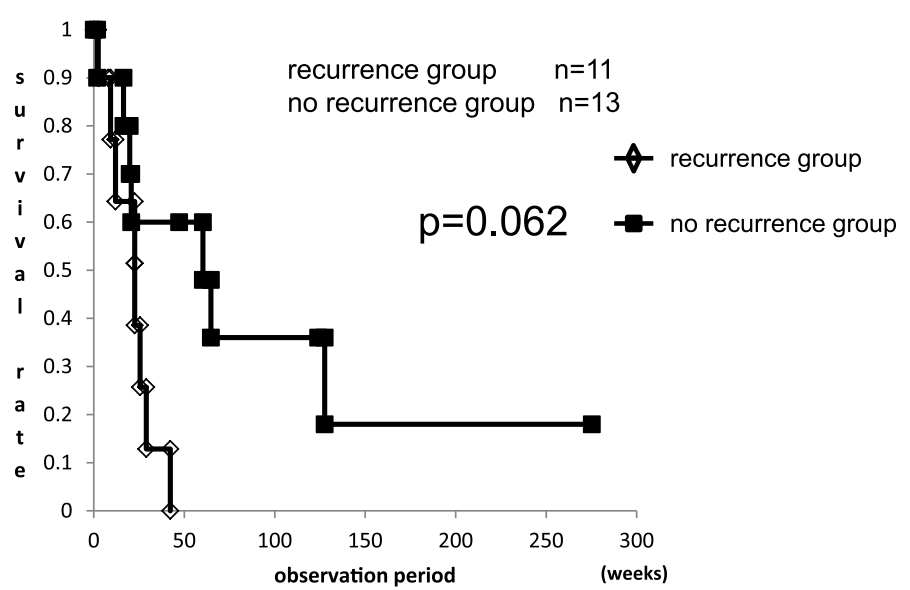

Figure 3. Survival curves for a) all patients and b) patients with advanced disease in the recurrence and no recurrence groups after initial VTE occurred. The survival time of all patients in the recurrence group was significantly shorter (a) $p=0.016)$ and that of patients with advanced disease in the recurrence group tended to be shorter than patients in the no recurrence group (b) $\mathrm{p}=0.062$ ).

る必要がある。

本論文内容に関連する著者の利益相反：なし

\section{REFERENCES}

1. Trousseau A. Phlegmasia alba dolens. In: Clinique Medicale de L'Hotel-Dieu de Paris. 2nd ed. Paris: JB Bailliere; 1865:654-712.

2. Bick RL. Cancer-associated thrombosis. $N$ Engl J Med. 2003;349:109-111.

3. Kasthuri RS, Taubman MB, Mackman N. Role of tissue factor in cancer. J Clin Oncol. 2009;27:4834-4838.

4. 岡崎智治, 新名主宏一. 悪性腫瘍に伴う血栓・塞栓症の発 症率および発症機序に関する検討. 医学検査. 2011;60:39.

5. Chew HK, Davies AM, Wun T, Harvey D, Zhou H, White $\mathrm{RH}$. The incidence of venous thromboembolism among patients with primary lung cancer. J Thromb Haemost. 2008;6:601-608.

6. Lyman GH, Bohlke K, Khorana AA, Kuderer NM, Lee AY, Arcelus JI, et al. Venous thromboembolism prophylaxis and treatment in patients with cancer: american society of clinical oncology clinical practice guideline update 2014. J Clin Oncol. 2015;33:654-656.

7. Mandalà M, Falanga A, Roila F. Management of venous thromboembolism (VTE) in cancer patients: ESMO Clinical Practice Guidelines. Ann Oncol. 2011;22(Suppl 6):vi85vi92.

8. Lee AY, Levine MN, Baker RI, Bowden C, Kakkar AK, Prins M, et al. Low-molecular-weight heparin versus a coumarin for the prevention of recurrent venous thromboembolism in patients with cancer. $N$ Engl J Med. 2003;
349:146-153.

9. Meyer G, Marjanovic Z, Valcke J, Lorcerie B, Gruel Y, Solal-Celigny $\mathrm{P}$, et al. Comparison of low-molecularweight heparin and warfarin for the secondary prevention of venous thromboembolism in patients with cancer: a randomized controlled study. Arch Intern Med. 2002;162: 1729-1735.

10. 肺血栓塞栓症/深部静脈血栓症（静脈血栓塞栓症）予防ガ イドライン作成委員会. 総論. 肺血栓塞栓症/深部静脈血 栓症 (静脈血栓塞栓症) 予防ガイドライン. 東京 : メディ カルフロントインターナショナルリミテッド； 2009.

11. Eichinger S, Minar E, Bialonczyk C, Hirschl M, Quehenberger P, Schneider B, et al. D-dimer levels and risk of recurrent venous thromboembolism. JAMA. 2003; 290:1071-1074.

12. 池田正孝, 竹政伊知朗, 水島恒和, 山本浩文, 関本貢嗣, 左近賢人, 他. 消化器癌と血栓症. 血液フロンティア. 2008;18:1569-1574.

13. Connolly GC, Khorana AA. Emerging risk stratification approaches to cancer-associated thrombosis: risk factors, biomarkers and a risk score. Thromb Res. 2010;125(Suppl 2):S1-S7.

14. Adess M, Eisner R, Nand S, Godwin J, Messmore HL Jr, Wehrmacher WH. Thromboembolism in cancer patients: pathogenesis and treatment. Clin Appl Thromb Hemost. 2006;12:254-266.

15. Blom JW, Osanto S, Rosendaal FR. The risk of a venous thrombotic event in lung cancer patients: higher risk for adenocarcinoma than squamous cell carcinoma. J Thromb Haemost. 2004;2:1760-1765.

16. 原 信之, 古藤 洋, 桑野和善. 血栓性動静脈疾患の病 態：悪性腫瘍. 日本臨床. 1999;57:1648-1652.

17. Pineo GF, Regoeczi E, Hatton MW, Brain MC. The activation of coagulation by extracts of mucin: a possible 
pathway of intravascular coagulation accompanying adenocarcinomas. J Lab Clin Med. 1973;82:255-266.

18. Loreto MF, De Martinis M, Corsi MP, Modesti M, Ginaldi L. Coagulation and cancer: implications for diagnosis and management. Pathol Oncol Res. 2000;6:301-312.

19. Sato T, Tsujino I, Ikeda D, Ieko M, Nishimura M. Trousseau's syndrome associated with tissue factor produced by pulmonary adenocarcinoma. Thorax. 2006;61:10091010.

20. Weitz JI. Low-molecular-weight heparins. $N$ Engl J Med. 1997;337:688-698.

21. Palareti G, Cosmi B, Legnani C, Tosetto A, Brusi C, Iorio $\mathrm{A}$, et al. D-dimer testing to determine the duration of anticoagulation therapy. N Engl J Med. 2006;355:1780-1789.

22. Putterman C, Tadmor B, Simer L, Caraco Y. Recurrent venous thrombosis as the presenting sign of two pri- mary lung carcinomas--15 years apart. Respir Med. 1992; 86:521-523.

23．金本幸司，松野洋輔，籠橋克紀，佐藤浩昭，大塚盛男，関 沢清久. 血栓塞栓症を合併した肺癌症例の臨床的検討. 日 呼吸会誌. 2002;40:863-868.

24. 杉野圭史, 磯部和順, 菊地 直, 村松陽子, 佐野 剛, 高 井雄二郎, 他. 静脈血栓塞栓症を合併した原発性肺癌患者 の臨床的検討. 肺癌. 2009;49:151-156.

25. Kourelis TV, Wysokinska EM, Wang Y, Yang P, Mansfield AS, Tafur AJ. Early venous thromboembolic events are associated with worse prognosis in patients with lung cancer. Lung Cancer. 2014;86:358-362.

26. Hokusai-VTE Investigators, Büller HR, Décousus H, Grosso MA, Mercuri M, Middeldorp S, et al. Edoxaban versus warfarin for the treatment of symptomatic venous thromboembolism. N Engl J Med. 2013;369:1406-1415. 